\title{
National Ignition Facility Quality Assurance Plan for Laser Materials \& Optical Technology
}

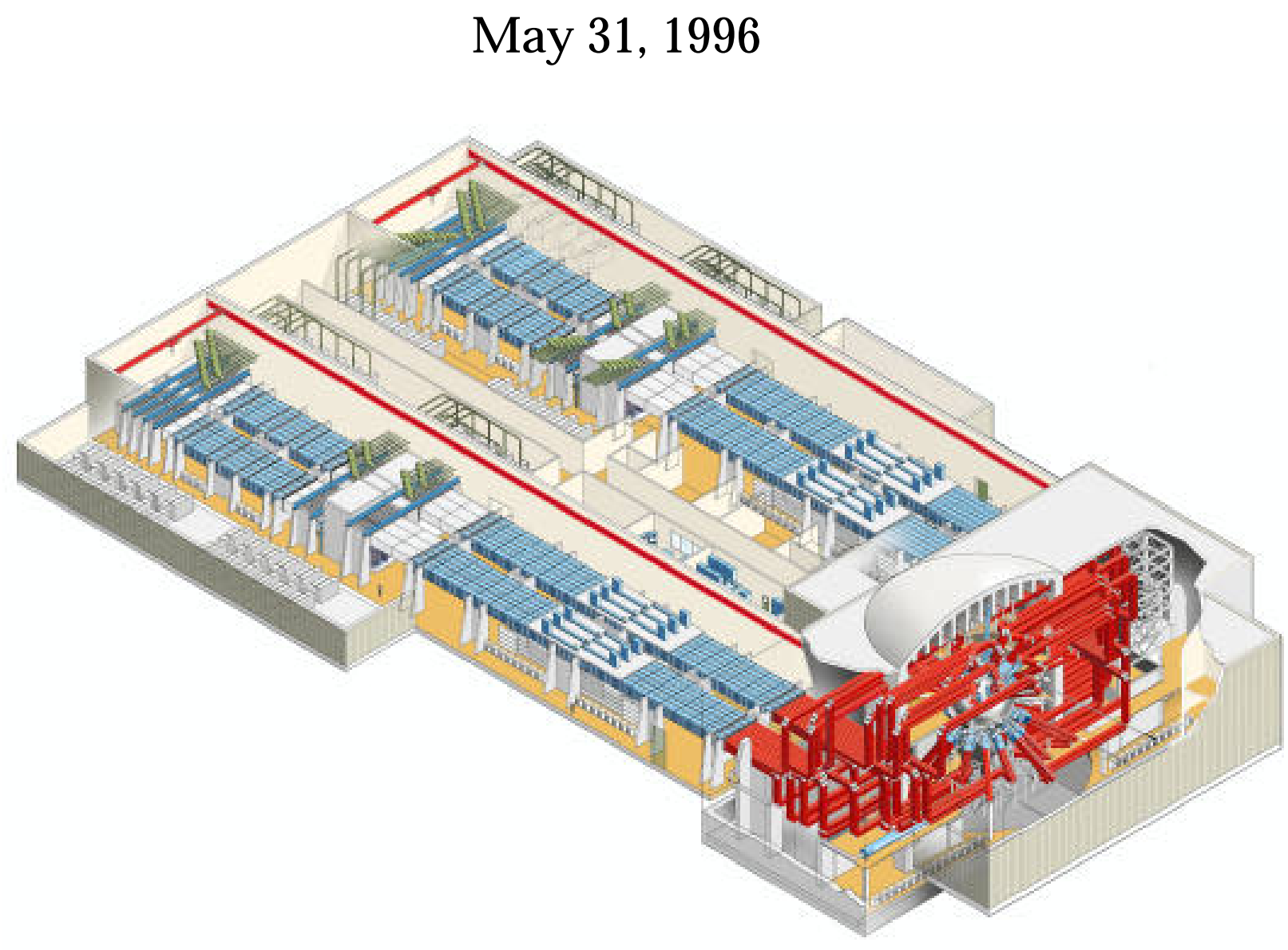

\section{近}

LAWRENCE LIVERMORE NATIONAL LABORATORY University of California • Livermore, California • 94550 


\section{DISCLAIMER}

This document was prepared as an account of work sponsored by an agency of the United States Government. Neither the United States Government nor the University of California nor any of their employees, makes any warranty, express or implied, or assumes any legal liability or responsibility for the accuracy, completeness, or usefulness of any information, apparatus, product, or process disclosed, or represents that its use would not infringe privately owned rights. Reference herein to any specific commercial products, process, or service by trade name, trademark, manufacturer, or otherwise, does not necessarily constitute or imply its endorsement, recommendation, or favoring by the United States Government or the University of California. The views and opinions of authors expressed herein do not necessarily state or reflect those of the United States Government or the University of California, and shall not be used for advertising or product endorsement purposes.

This report has been reproduced directly from the best available copy.

Available to DOE and DOE contractors from the Office of Scientific and Technical Information P.O. Box 62, Oak Ridge, TN 37831

Prices available from (615) 576-8401, FTS 626-8401

Available to the public from the

National Technical Information Service

U.S. Department of Commerce

5285 Port Royal Rd.

Springfield, VA 22161

Work performed under the auspices of the U.S. Department of Energy by Lawrence Livermore National Laboratory under Contract W-7405-Eng-48. 


\section{National Ignition Facility \\ Quality Assurance Plan \\ for}

Laser Materials \& Optical Technology

May 31, 1995

Prepared by:

C. R. Wolfe, date

NIF QA Manager

Reviewed by:

D. M. Aikens, date

NIF Optics Production Manager

Approved by:

L. J. Atherton, date

Associate Project Leader for

Laser Materials \& Optical Technology 


\section{Contents}

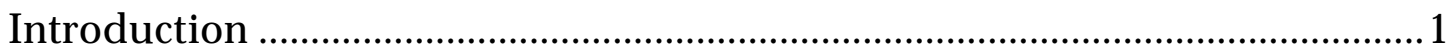

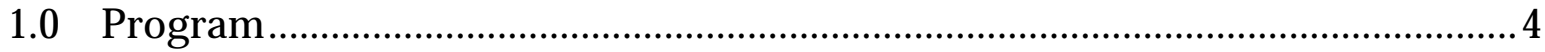

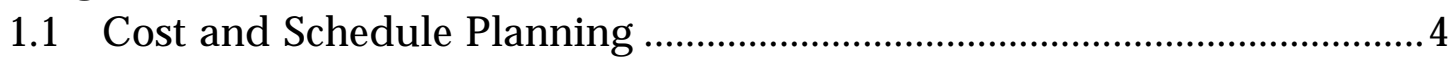

1.2 LM\&OT Management System ………………........................................

1.2.1 Management Planning ………………………..................................

1.2.2 Work Breakdown Structure .................................................................

1.2.3 Organizational Structure .................................................................

1.2.4 Roles and Responsibilities ..............................................................

1.2.5 Risk assessment-Quality Assurance Levels ....................................9

2.0 Personnel Training and Qualifications ................................................................... 10

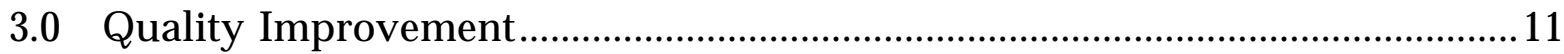

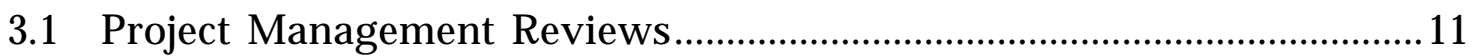

3.2 Control of Nonconformances ……………...........................................11

3.3 Corrective Action ........................................................................................

3.4 Performance Measurement_future …………………………………...12

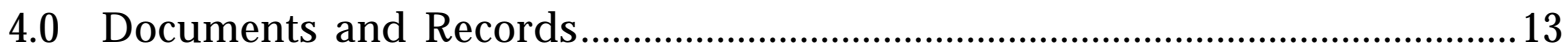

4.1 Document and Records Management ....................................................13

4.2 Supplier use of the LM\&OT QA Plan ........................................................13

5.0 Work Processes ..............................................................................................

5.1 The Design Review Process .......................................................................14

5.2 Calibration of Measurement and Test Equipment-future.......................15

5.3 Preventive Maintenance-future ................................................................15

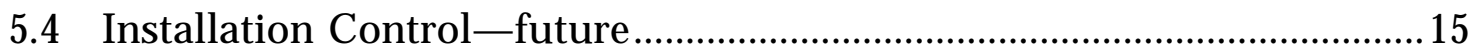

5.5 Handling, Storage, and Shipping ............................................................15

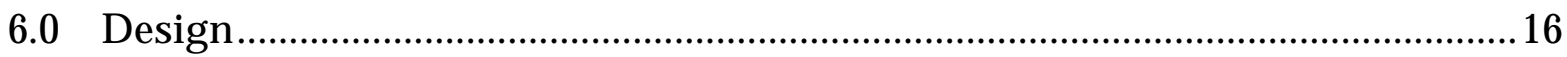

6.1 Design Criteria Preparation and Control .................................................16

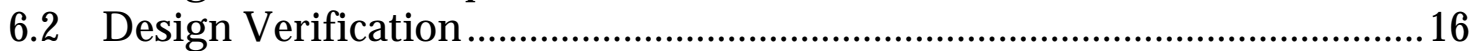

6.3 Configuration Management......................................................................16

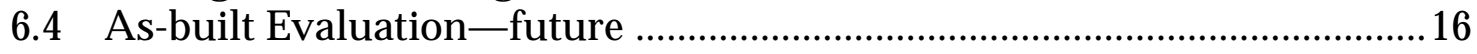

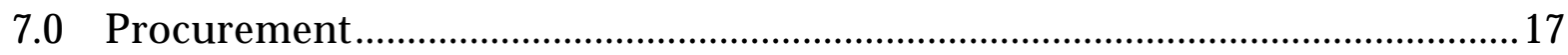

7.1 Procurement Document Preparation and Control ………........................17

7.2 Vendor Qualification and Qualified Bidder Assessment ............................17

7.3 Vendor Surveys .......................................................................................... 17 
8.0 Inspection and Acceptance Testing...................................................................18

8.0.1 Material review and disposition during optics facilitization and pilot production ............................................18

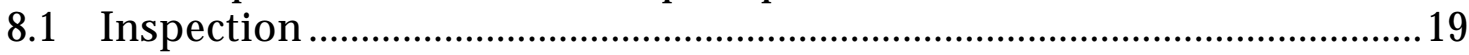

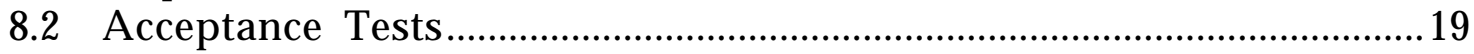

8.3 Certification of Vendors.........................................................................19

9.0 Management Assessment...................................................................................20

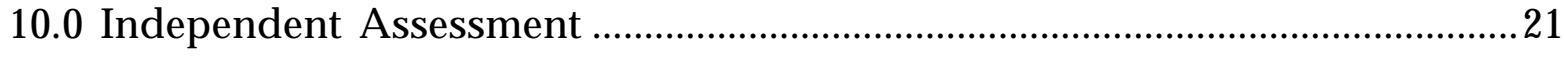

Appendix A. Laser Materials and Optical Technology

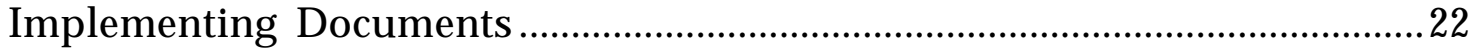

Appendix B. Laser Materials and Optical Technology

Implementing Organization.............................................................................2

\section{Tables}

Table 1-1. Quality Assurance Organization Plan Elements ........................................

Table 1-2. LM\&OT Management Planning Documents ................................................5

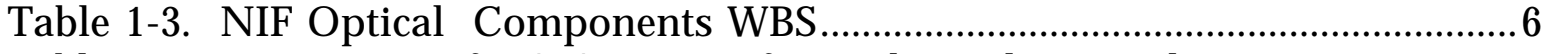

Table 1-4. Description of QA Activities for Each Quality Level.................................9 


\section{Acronyms}

$\begin{array}{ll}\text { APL } & \text { associate program leader } \\ \text { CS\&T } & \text { core science and technology } \\ \text { DOE } & \text { Department of Energy } \\ \text { LM\&OT } & \text { Laser Materials \& Optical Processing (organization) } \\ \text { MRB } & \text { material review board } \\ \text { NCR } & \text { nonconformance report } \\ \text { NIF } & \text { National Ignition Facility } \\ \text { OPC } & \text { other project costs } \\ \text { PACE } & \text { plant and capital equipment } \\ \text { QA } & \text { quality assurance } \\ \text { QAP } & \text { quality assurance plan } \\ \text { QAPP } & \text { quality assurance program plan } \\ \text { SDR } & \text { system design requirement } \\ \text { SSDR } & \text { subsystem design requirement } \\ \text { WBS } & \text { work breakdown structure }\end{array}$




\section{Introduction}

Quality achievement is the responsibility of the line organizations of the National Ignition Facility (NIF) Project. This subtier Quality Assurance Plan (QAP) applies to activities of the Laser Materials \& Optical Technology (LM\&OT) organization and its subcontractors. It responds to the NIF Quality Assurance Program Plan (QAPP, L-15958-2, NIF-95-499) and Department of Energy (DOE) Order 5700.6C.

This Plan is organized according to 10 Quality Assurance (QA) criteria and subelements of a management system as outlined in the NIF QAPP and listed in Table 1-1. This Plan describes how those QA requirements are met. Table 1-1 indicates the location of QA requirements in the NIF QAPP and where the implementation description can be found in this document. Appendix A is included for reference as a summary of other documents that further describe implementation for the LM\&OT organization.

This Plan is authorized by the Associate Project Leader for the LM\&OT organization, who has assigned responsibility to the Optics QA engineer to maintain this plan, with the assistance of the NIF QA organization. This Plan governs quality-affecting activities associated with:

- Design

- Procurement

- Fabrication

- Testing and acceptance

- Handling and storage

- Installation of NIF Project optical components into mounts and subassemblies.

The LM\&OT organization, responsibility, and interfaces are described in Section 1.2. By issuing this QA Plan, the Associate Program Leader for the LM\&OT organization has established the following:

- Responsibility and authority for developing and implementing a quality plan for the organization.

- The requirement that its quality organization meets applicable federal codes, standards, and regulations.

- The requirement that effective QA activities be implemented by the LM\&OT organization and its subcontractors.

- The requirement that issues adverse to quality be identified and that corrective action be taken when necessary. 
This Plan addresses Title I and II engineering design and the parallel LM\&OT activities associated with optics facilitization and pilot production. The Project has committed to phased implementation of QA activities according to an overall schedule contained in the NIF QAPP. This means that during the certain Project phases, work descriptions will be prepared in the form of written procedures. Approved procedures governing the activities of the NIF Project organizations are contained in the Project Control Manual, (L-21254-1, NIF-96-041). This Plan will be updated at Critical Decision 3 to incorporate procurement, Title III engineering, inspection, and acceptance. 
Table 1-1. Quality Assurance Organization Plan Elements.

\begin{tabular}{|c|c|c|}
\hline QA Criteria & NIF QAPP & $\begin{array}{c}\text { LM\&OT QA } \\
\text { Plan }\end{array}$ \\
\hline \multicolumn{3}{|l|}{ Management Criteria } \\
\hline \multicolumn{3}{|l|}{ Criterion 1: Program } \\
\hline 1.1 Quality Assurance Procedures & 6.1.1.1 & Intro. \\
\hline 1.2 Ancillary Quality Assurance Plans & 6.1 .1 .2 & - \\
\hline 1.3 Cost and Schedule Planning & 6.1.1.3 & 1.1 \\
\hline 1.4 Management System & - & 1.2 \\
\hline \multicolumn{3}{|l|}{ Criterion 2: Personnel Training and Qualifications } \\
\hline 2.1 Professional qualifications & - & 2.0 \\
\hline 2.2 Project specific training & - & 2.0 \\
\hline \multicolumn{3}{|l|}{ Criterion 3: Quality Improvement } \\
\hline 3.1 Project Reviews & 6.1.3.1 & 3.1 \\
\hline 3.2 Nonconforming Items & 6.1 .3 .2 & 3.2 \\
\hline 3.3 Corrective Actions & 6.1 .3 .3 & 3.3 \\
\hline 3.4 NIF Quality-Improvement Activities & 6.1.3.4 & - \\
\hline 3.5 Performance Measurement & - & 3.4 \\
\hline \multicolumn{3}{|l|}{ Criterion 4: Documents and Records } \\
\hline 4.1 Document Control & 6.1.4.1 & 4.0 \\
\hline 4.2 Record Control & 6.1.4.2 & 4.0 \\
\hline 4.3 Standard Distribution Processes & 6.1 .4 .3 & 4.0 \\
\hline \multicolumn{3}{|l|}{ Performance Criteria } \\
\hline \multicolumn{3}{|l|}{ Criterion 5: Work Processes } \\
\hline 5.1 Design Review Process & 6.2.1.1 & 5.1 \\
\hline 5.2 Calibration of Measurement and Test Equipment & 6.2 .1 .2 & 5.2 \\
\hline 5.3 Preventive Maintenance & 6.2.1.3 & 5.3 \\
\hline 5.4 Installation Control & 6.2 .1 .4 & 5.4 \\
\hline 5.5 Handling, Storage, and Shipping & 6.2 .1 .5 & 5.5 \\
\hline \multicolumn{3}{|l|}{ Criterion 6: Design } \\
\hline 6.1 Design Criteria Preparation and Control & 6.2.2.1 & 6.1 \\
\hline 6.2 Configuration Management & 6.2 .2 .2 & 6.2 \\
\hline 6.3 Design Verification & 6.2 .2 .3 & 6.3 \\
\hline 6.4 As-built Evaluation & 6.2.2.4 & 6.4 \\
\hline \multicolumn{3}{|l|}{ Criterion 7: Procurement } \\
\hline 7.1 Procurement Document Preparation and Control & 6.2.3.1 & 7.1 \\
\hline 7.2 Vendor Qualification and Bidder Assessment & 6.2 .3 .2 & 7.2 \\
\hline 7.3 Vendor Surveillance & - & 7.3 \\
\hline \multicolumn{3}{|l|}{ Criterion 8: Inspection and Acceptance Testing } \\
\hline 8.1 Inspection Levels & 6.2.4.1 & 8.1 \\
\hline 8.2 Acceptance Tests & 6.2 .4 .2 & 8.2 \\
\hline 8.3 Certification of Vendors & 6.2 .4 .3 & 8.3 \\
\hline \multicolumn{3}{|l|}{ Assessment Criteria } \\
\hline Criterion 9: Management Assessment & 6.3 .1 & 9.0 \\
\hline Criterion 10: Independent Assessment & 6.3 .2 & 10.0 \\
\hline
\end{tabular}




\subsection{Program}

Criterion 1 of the NIF QAPP, "Program," requires that:

- A QA organization be developed.

- Organization, roles, and responsibilities be defined.

- A management system be described.

This section describes how these requirements are implemented in the LM\&OT organization.

\subsection{Cost and Schedule Planning}

Cost and schedule planning for LM\&OT activities is performed according to the following approved NIF project control procedures:

- 1.2-Procedure for Plant and Capital Equipment Cost Estimate Preparation and Revision.

- 1.3-Procedure for Schedule Preparation and Revision.

- 1.4-Procedure for Cost Trend Preparation.

\subsection{LM\&OT Management System}

The management of Project activities within the LM\&OT organization is described in the following sections.

\subsubsection{Management Planning}

Work controls are developed through a process of defining the work to be accomplished within the context of the Project Execution Plan (L-19549-3, NIF-96-045). The management planning documents shown in Table 1-2 define the work scope details within the LM\&OT organization. To accomplish this, planning documents address basic questions such as:

- What actions are required?

- How will these tasks be performed?

- Who will perform them?

- When will the tasks be performed? 
Table 1-2. LM\&OT Management Planning Documents.

\begin{tabular}{|c|c|}
\hline Title & Description \\
\hline Metrology Plan & $\begin{array}{l}\text { - Measurements flow down from system } \\
\text { design requirements (SDRs). } \\
\text { - Instruments and test procedures needed }\end{array}$ \\
\hline Optics Handling and Processing Plan & $\begin{array}{l}\text { - Handling requirements flow down from } \\
\text { SDRs. } \\
\text { - Process flow, instruments, and procedures } \\
\text { as needed }\end{array}$ \\
\hline NIF Optics Production Plan (proprietary) & $\begin{array}{l}\text { - Will maximize value to the Project. } \\
\text { - Includes Optics Facilitization Plan and } \\
\text { production methodology. } \\
\text { - Based upon Core Science and Technology } \\
\text { (CS\&T) development program results, } \\
\text { vendor cost studies. }\end{array}$ \\
\hline NIF Acquisition Plan & $\begin{array}{l}\text { A top-level acquisition plan that } \\
\text { describes the schedule and method of } \\
\text { subcontracting. }\end{array}$ \\
\hline Vendor Qualification Plan & $\begin{array}{l}\text { - Provides detail of the generic process } \\
\text { described by NIF Procedure 7.1. }\end{array}$ \\
\hline CS \& T Development Plans & $\begin{array}{l}\text { Plans developed as part of the CS\&T } \\
\text { organization and budget cycle, action is } \\
\text { dictated by NIF Project baseline } \\
\text { requirements. }\end{array}$ \\
\hline others (TBD_ & - \\
\hline
\end{tabular}

\subsubsection{Work Breakdown Structure}

The Work Breakdown Structure (WBS) for the LM\&OT organization work is contained in the Project WBS, L-16723-2, NIF-95-598. Both Plant and Capital Equipment (PACE) and Other Project Costs (OPC) funded activities are involved in LM\&OT work as shown in Table 1-3. The primary interfaces with NIF Project are also indicated. In addition, all optical components interface to the following WBS elements:

- WBS 1.6.10, Optical Component Integration

- WBS 1.4.4, Optical Mounts.

Optical components that are not included in the scope of LM\&OT activities are:

- Laser diagnostic optical components and subassemblies, which are contained in WBS 1.7, Laser Control.

- Experimental systems optical components and subassemblies, which are contained in WBS 1.8, Target Experimental System.

Another activity not included in the work scope of LM\&OT is the installation of subassemblies into the NIF. These activities are conducted under WBS 1.10.2, Activation. 
Table 1-3. NIF Optical Components WBS.

\begin{tabular}{|c|c|c|c|c|}
\hline NIF Optical Components & $\begin{array}{c}\text { PACE } \\
\text { funded } \\
\text { elements }\end{array}$ & $\begin{array}{l}\text { Position } \\
\text { responsible }\end{array}$ & $\begin{array}{c}\text { Primary } \\
\text { interface } \\
\text { element }(s) \\
\end{array}$ & Primary interface title(s) \\
\hline Amplifier slabs & 1.6 .1 & $\begin{array}{l}\text { Laser Glass } \\
\text { R\&D }\end{array}$ & $\begin{array}{l}1.3 .2 \\
1.4 .3\end{array}$ & $\begin{array}{l}\text { Amplifier system } \\
\text { Support structures }\end{array}$ \\
\hline Lenses & 1.6 .2 & $\begin{array}{l}\text { Optical } \\
\text { Components }\end{array}$ & $\begin{array}{l}1.4 .1 \\
1.8 .7\end{array}$ & $\begin{array}{l}\text { Spatial filter vessels and } \\
\text { enclosures } \\
\text { Final optics assemblies }\end{array}$ \\
\hline Mirrors & 1.6 .3 & $\begin{array}{l}\text { Optical } \\
\text { Components }\end{array}$ & $\begin{array}{l}1.4 .3 \\
1.8 .4 \\
\end{array}$ & $\begin{array}{l}\text { Support structures } \\
\text { Target Area structures }\end{array}$ \\
\hline Polarizers & 1.6 .4 & $\begin{array}{l}\text { Optical } \\
\text { Components }\end{array}$ & $\begin{array}{l}1.3 .3 \\
1.4 .3 \\
\end{array}$ & $\begin{array}{l}\text { Pockels cell system } \\
\text { Support structures }\end{array}$ \\
\hline $\mathrm{KDP}$ and $\mathrm{KD}^{*} \mathrm{P}$ crystals & 1.6 .5 & KDP Crystals & $\begin{array}{l}1.3 .3 \\
1.8 .7 \\
\end{array}$ & $\begin{array}{l}\text { Pockels cell system } \\
\text { Final optics assemblies }\end{array}$ \\
\hline Debris shields and windows & 1.6 .6 & Final Optics & 1.8.7 & Final optics assemblies \\
\hline Pulse generation optics & 1.6 .7 & $\begin{array}{l}\text { Optical } \\
\text { Components }\end{array}$ & 1.3.1 & Optical pulse generation \\
\hline Optical component processing & 1.6 .8 & $\begin{array}{l}\text { Optical } \\
\text { Components }\end{array}$ & $\begin{array}{l}\text { all } 1.6 . X \\
1.2 .2 .3 \\
\end{array}$ & - \\
\hline QA and damage testing & 1.6 .9 & QA/Metrology & all 1.6.X & - \\
\hline $\begin{array}{l}\text { Optical component } \\
\text { integration }\end{array}$ & 1.6.10 & $\begin{array}{l}\text { NIF Optics } \\
\text { Production }\end{array}$ & $\begin{array}{l}\text { all 1.6.X } \\
1.10 .2 \\
\end{array}$ & $\begin{array}{l}- \\
\text { Activation } \\
\end{array}$ \\
\hline NIF Technical support & $\begin{array}{c}\text { OPC } \\
\text { funded } \\
\text { elements }\end{array}$ & $\begin{array}{l}\text { Position } \\
\text { responsible }\end{array}$ & $\begin{array}{c}\text { Primary } \\
\text { interface } \\
\text { element }(s)\end{array}$ & Primary interface title(s) \\
\hline Optics facilitization & 1.11.6.1 & $\begin{array}{l}\text { NIF Optics } \\
\text { Production }\end{array}$ & $\begin{array}{l}1.11 .6 .2 \\
1.11 .6 .4 \\
\end{array}$ & $\begin{array}{l}\text { Optics pilot production } \\
\text { Optics manufacturing } \\
\text { integration }\end{array}$ \\
\hline Optics pilot production & 1.11.6.2 & $\begin{array}{l}\text { NIF Optics } \\
\text { Production }\end{array}$ & all 1.6.X & $\begin{array}{l}\text { Optics manufacturing } \\
\text { integration }\end{array}$ \\
\hline Optics QA and processing & 1.11.6.3 & QA/Metrology & $\begin{array}{l}1.6 .8 \\
1.6 .9 \\
1.2 .2 .3 \\
\end{array}$ & $\begin{array}{l}\text { Optical component } \\
\text { processing } \\
\text { QA and damage testing } \\
\text { Optics assembly building }\end{array}$ \\
\hline $\begin{array}{l}\text { Optics manufacturing } \\
\text { integration }\end{array}$ & 1.11.6.4 & $\begin{array}{l}\text { NIF Optics } \\
\text { Production }\end{array}$ & $\begin{array}{ll}\text { all } & 1.6 . X \\
\text { all } & 1.6 . X \\
\end{array}$ & - \\
\hline $\begin{array}{l}\text { First article production- } \\
\text { optical component articles }\end{array}$ & 1.11.6.5.4 & LM\&OT APL & all 1.6.X & - \\
\hline
\end{tabular}




\subsubsection{Organizational Structure}

The structure of the LM\&OT organization is shown in Appendix B. The organization includes personnel responsible for achieving quality and those responsible for verification of quality achievement. Verifications are performed by personnel other than those who are responsible for performing the work.

Verification personnel, whether in the line organization or independent, have sufficient access and authority to:

- Identify quality problems or nonconformance with requirements.

- Initiate, recommend, or provide solutions.

- Verify implementation of corrective actions.

- Ensure that nonconforming work is either stopped or proceeding under controlled conditions until proper disposition of the unsatisfactory condition is accomplished.

\subsubsection{Roles and Responsibilities}

The quality-related responsibilities of key management positions of the LM\&OT organization are described below. Authority to perform the duties listed may be delegated to other qualified individuals; however, the responsibility remains with the position named.

1.2.4.1 The Associate Program Leader (APL) for LM\&OT is responsible for:

- Establishing goals and prioritizing work for the organization.

- Implementing this QA Plan throughout the organization.

- Interfacing with the NIF Project and the DOE.

- Planning and managing the manpower and resources to accomplish the work scope of the organization.

1.2.4.2 The NIF Optics Production Manager is responsible for:

- Optical component production as required to achieve the NIF Project baselines (i.e., performance, cost, and schedule).

- Developing and implementing a vendor qualification plan and organization

- Managing production to maximize value to the Project.

- Managing activities of the Materials Review Board (MRB), as Chairman.

- Assigning quality levels (Q-levels)

1.2.4.3 The NIF Optical Components Manager is responsible for:

- Producing optical components.

- Developing and implementing a vendor qualification program.

- Implementing and managing vendor contracts to meet the NIF project schedule. 
1.2.4.4 The Lead Engineers/Scientists for Optical Component Development are responsible for:

- The technical direction of assigned optical component development activities.

- Planning and conducting technology development tasks in their areas of responsibility.

- Reviewing System Design Requirements (SDRs) for components.

- Reviewing written production plans and schedules.

- Reviewing Q-levels.

- Participating as needed, in MRB deliberations.

- Providing input to the optics drawings.

1.2.4.5 The Optical Specification Engineer is responsible for:

- Reviewing the SDRs and subsystem SDRs (SSDRs) and translating these into large optics specifications.

- Preparing the optics drawings necessary for bidding facilitization, pilot production, and production contracts.

- Participating as needed, in MRB deliberations.

1.2.4.6 The Optics Quality/Metrology Engineer is responsible for:

- Maintaining this plan for each phase of the NIF Project.

- Ensuring that work procedures adequately describe LM\&OT work process (including subcontractor documents).

- Developing a training organization and assuring that training records are kept.

- Training personnel to perform quality verification tasks, as appropriate.

- Developing and implementing a quality audit plan.

- Serving as Secretary of the MRB.

- Creating and performing source inspections as needed.

- Preparing metrology plans for testing optical components that describe the measurements required, how and when they are performed.

- Developing and recommending metrology instruments for inspection of optical components.

- Preparing work procedures for test and inspection activities.

- Training personnel to perform part inspections.

1.2.4.7 The Optics Production Control Leader is responsible for:

- Developing individual and master schedules.

- Developing and implementing schedule maintenance, tracking, and statusing methodologies.

- Interfacing with optics vendors to track their schedules.

1.2.4.8 The Optics Processing Group Leader is responsible for:

- Preparing the Optics Processing and Handling Plan.

- Implementing optical component receiving and inspection systems.

- Implementing optical component cleaning processes.

- Implementing sol-gel coating processes. 
- Implementing optical component assembly, packaging, and handling systems.

- Preparing optics-processing work procedures.

Each individual in the LM\&OT organization is responsible for achieving quality in his or her own work. Technical and administrative personnel, including subcontractors and consultants, are responsible for ensuring that their work is performed in accordance with this Plan, Project procedures, and approved subcontractor procedures.

\subsubsection{Risk assessment-Quality Assurance Levels}

The use of Q-levels within the LM\&OT organization will be implemented according to NIF Procedure 1.6, "Assignment of Q-Levels." Three Q-levels for optical components are defined. The use of Q-levels supports a graded approach to focus greatest effort on the most important activities. Assigning Q-levels is the responsibility of LM\&OT Lead Engineers/Scientists (the technical authority), working in cooperation with the NIF QA staff. The Q-level applied to an optical component or associated activity is determined by assessing the consequences in the event of a failure of the item. This is based on scientific and engineering judgment and management experience. The possible failure consequences are grouped according to impact on:

- Environment

- Health and safety

- Technical performance

- Project budget

- Schedule

A summary description of QA activities associated with each Q-level is contained in Table 1-4. The amount of formal documentation required by Q-level 1 is the highest; other levels require less. It is important to note that, except for Q-level 3, the QA activities described in Table 1-4 are in addition to commonly accepted commercial and national consensus codes and standards specified for all items. QA effort above this baseline provides traceability of compliance with requirements for items of high potential impact to the Project.

Table 1-4. Description of QA Activities for Each Quality Level

\begin{tabular}{|c|l|}
\hline Q-level & \multicolumn{1}{|c|}{ Description of quality assurance activity } \\
\hline 1 & $\begin{array}{l}\text { Full formalized QA documentation, verification and audit activities for the work } \\
\text { involved. }\end{array}$ \\
\hline 2 & $\begin{array}{l}\text { Formal QA documentation, verification, and periodic audits for some aspects of the } \\
\text { work. }\end{array}$ \\
\hline 3 & $\begin{array}{l}\text { Documentation and verification that meets national consensus standards (Q-level } 3 \text { is } \\
\text { the default level). }\end{array}$ \\
\hline
\end{tabular}




\subsection{Personnel Training and Qualifications}

Criterion 2 of the NIF QAPP, "Personnel Training and Qualifications," requires that:

- Trained personnel are assigned to the correct tasks.

- Continued training is available to ensure proficiency.

NIF Project personnel who are assigned to manage, perform, or verify activities that affect quality receive appropriate orientation and training prior to performing the assigned work. The training required is determined by the organization managers in accordance with NIF Procedure 2.2, "Personnel Training and Qualification."

Training of subcontractor personnel is verified by examination of personnel qualification records, surveillance of work in progress, and assessment of output products. These verification tasks are part of the testing and inspection activity discussed in the NIF QAPP Section 6.2.4.3, "Certification of Vendors," and in Sections 7.2 and 7.3 of this document. 


\subsection{Quality Improvement}

Criterion 3 of the NIF QAPP, "Quality Improvement," requires that processes be implemented to:

- Detect and prevent quality problems.

- Identify, control, and correct items and activities that do not meet requirements.

- Identify causes of problems to prevent recurrence.

\subsection{Project Management Reviews}

Routine Project reviews of Title I work are planned for the LM\&OT organization. A discussion of design activities during Title I is provided in the NIF Title I Design Plan, L-20357-1, NIF-95-650. Project design reviews are conducted according to NIF Procedure 5.1, "Title I Design Review." Additional reviews are planned and performed as needed.

\subsection{Control of Nonconformances}

Implementation of OPC-funded activities in this area is described in Section 8.0.1.

Implementation of procedures for PACE-funded activities specific to this organization will not occur until the optics procurement phase of work. The following paragraph summarizes LM\&OT policy.

Each person has the responsibility to identify conditions adverse to quality, and report them to appropriate management by means of a Nonconformance Report (NCR), according to NIF Procedure 3.2, "Nonconformance Reporting," or its approved subcontractor equivalent. Deficient conditions are investigated and dispositions are determined by the appropriate technical authority. Deficiencies identified by inspections, assessments, or other reviews are also reported on NCRs, which are periodically analyzed for possible trends to identify opportunities for improvement.

\subsection{Corrective Action}

Implementation of OPC-funded activities in this area is described in Section 8.0.1.

Implementation of the procedure, for PACE activities, specific to this organization will not occur until optics procurement phase of work. The following paragraph summarizes management policy.

As part of the nonconformance control process, consideration is given to root causes and generic implications, and corrective action is taken according to the methods established in that process. When necessary, further action will be taken to prevent recurrence of reported deficiencies. 


\subsection{Performance Measurement-future}

Performance standards for individual activities are established in the procedures that govern the work. Information on compliance with performance requirements is collected and analyzed through the nonconformance/corrective action processes described above. This process provides the necessary feedback information for NIF Project technical personnel to address problems commensurate with their Q-Level and the degree of importance and occurrence. 


\subsection{Documents and Records}

Criterion 4 of the NIF QAPP, "Documents and Records," requires that processes be implemented to:

- Manage, control, and maintain documents that describe processes, specify requirements, or establish designs.

- Manage, control, and maintain records that provide evidence of quality.

\subsection{Document and Records Management}

A system of managing records and documents that allows retrieval of pertinent organization or project files has been established by the NIF Project in Procedure 4.1, "Document and Records Control." NIF Project Procedure 4.2, "Control of Project Correspondence," describes the approved process of managing correspondence to and from the Project. These procedures apply to all work on the NIF Project, including the LM\&OT organization. Subcontractors are required by procurement documents to supply plans and procedures that describe their control of documents and records created as a result of subcontract work.

\subsection{Supplier use of the LM\&OT QA Plan}

In Q-Level 1 or 2 cases where the procurement scope or schedule constraints cannot justify supplier development or maintenance of a QA program, the LM\&OT organization may permit some or all of the suppliers activities to be performed under the jurisdiction of this document. Under these circumstances, the APL will ensure that procurement documents specify those portions of this QA Plan apply to the subcontractor's work. 


\subsection{Work Processes}

Criterion 5 of the NIF QAPP, "Work Processes," requires that processes be implemented to:

- Perform work to established technical standards and administrative controls.

- Use approved procedures to control work.

- Identify and control items to ensure proper use and prevent damage or loss.

- Calibrate and maintain equipment used for monitoring and data collection.

Production of optical components for the NIF requires the collaboration of Project staff and many fabricating subcontractors to complete the following:

- Production of optical materials.

- Fabrication of these materials into finished optical components.

- Inspection and testing of in-process and finished parts.

- Handling, storage, and shipping.

- Acceptance testing of optical systems and subsystems.

The LM\&OT organization develops such organization-specific work controls as needed. These documents are described in Appendix A. Subcontractors develop their own procedures governing their work scope. Subcontractors procedures will be reviewed and approved by the LM\&OT organization prior to the performance of work.

\subsection{The Design Review Process}

Project reviews of optics designed at LLNL for installation in NIF are conducted according to NIF Procedure 5.1, "Title I Design Review."

Most of the facilities and equipment related to optics production and metrology will be designed, built, installed, and operated by vendors. The exception is the final processing, testing, conditioning, and inspection equipment planned for testing and or processing optics prior to release for installation. The Optical Specifications Engineer is responsible for preparing the optics drawings and requirements necessary for bidding facilitization, pilot production, and production contracts. The lead engineer/scientist assigned to manage the respective facilitization contracts will participate in vendor design reviews as appropriate. Final acceptance of all deliverables shall be based on ensuring compliance with terms of the contract with the respective vendors. Part of this assurance will result from lead engineer/scientist participation in vendor design reviews and frequent vendor meetings. Upon determination that the contractual requirements for equipment, facilities, and systems have been met, the lead engineer/scientist will issue a "design complete" letter to the LM\&OT QA file.

Similarly, for equipment designed and built at LLNL for NIF optics metrology or processing applications, a review will be conducted to verify conformance to the performance requirements for the system, facility, or equipment. The lead system 
design engineer will use Procedure 5.1, "Title I Design Review," as a guide for the final design review and apply the procedure as applicable to the specific equipment. This equipment generally consists of test and conditioning systems that will be set up specifically for use by vendors and final inspections at LLNL.

\subsection{Calibration of Measurement and Test Equipment-future}

Processes used during OPC-funded activities are described in NIF Procedure TBD, "Metrology Instruments Calibration." Implementation procedures for PACE activities specific to this organization will not occur until the optics pilot production phase of work (in parallel with Title II engineering).

\subsection{Preventive Maintenance-future}

Implementation procedures for PACE activities specific to this organization will not occur until the equipment installation phase of work. However, optical design and prototyping activities will include development activities for future preventive maintenance in keeping with good engineering practice.

\subsection{Installation Control-future}

Implementation procedures for PACE activities specific to this organization will not occur until the production phase of work. Optical components will be identified in accordance with NIF Procedure 5.4, "Component Identification and Tagging." This procedure describes methods for tracking components and corresponding documentation from production through NIF operation.

Refer to Section 6.3, Configuration Management, and the NIF Optics Production Plan for additional discussion of activities relating to this topic.

\subsection{Handling, Storage, and Shipping}

Implementation procedures for PACE activities specific to this organization will not occur until the optics procurement/production phase of work. Planning, testing, and development are part of pilot production activities (in parallel with Title II engineering). As appropriate, the handling, storage, and shipping of items are specified in design drawings and specifications. These requirements are part of procurement documents for items fabricated by subcontractors. A distinction is made between Q-level 1 and 2 elements and Q-level 3 elements, primarily based upon impact in the event of loss. Handling, storage, labeling, shipping, cleaning, and preservation of Q-Level 1 and 2 components are accomplished in accordance with NIF Procedure TDB, "Optical Component Handling." These procedures are designed to prevent damage, loss, or deterioration, and to maintain acceptable quality of all optics components until installed in the NIF. Q-Level 3 components are handled in accordance with commercial practices. 


\subsection{Design}

Criterion 6 of the NIF QAPP, "Design," requires that designs:

- Use accepted engineering principles.

- Incorporate approved design bases and requirements into design work.

- Verify design bases with personnel who did not perform the work.

- Validate design work before approval and implementation.

\subsection{Design Criteria Preparation and Control}

Design criteria are prepared in accordance with the following NIF Project Procedures:

- 6.1-Preparation and Revision of System Design Requirements.

- 6.2-Preparation and Revision of Interface Control Documents.

Engineering drawings are prepared according to: NIF Procedure 6.3, "Engineering Drawing Standards and Control."

\subsection{Design Verification}

Design of LM\&OT systems and components are verified by qualified personnel implementing the processes described by the following NIF Procedures:

- 6.3-Engineering Drawing Standards and Controls.

- 6.4-Configuration Data Management.

\subsection{Configuration Management}

The NIF Project Configuration Management Plan (L-21635-1, NIF-96-070) which describes the methods of controlling system configuration and the method of implementation, applies to all Project work. This plan describes the relationship between the Project's baselines, design controls, and the change control process.

\subsection{As-built Evaluation-future}

The NIF Configuration Management Plan describes the review process for "as-built" information. Specifically, the nonconformance review/control process addresses disposition and documentation of hardware discrepancies. NIF Procedure 3.2, "Nonconformance Reporting," will describe these activities. 


\subsection{Procurement}

Criterion 7 of the NIF QAPP, "Procurement," requires that work controls be implemented to:

- Ensure that procured products and services meet established requirements.

- Evaluate and select suppliers on the basis of specified criteria.

- Ensure that suppliers continue to provide acceptable products and services.

The NIF Acquisition Plan (L-16865-2, NIF-94-062, Rev.1) describes the schedule, contracting plan, and method of vendor selection for NIF procurement. The NIF Optics Production Plan is a more specific description of the procurement rationale for optical components.

\subsection{Procurement Document Preparation and Control}

NIF Procedure 7.2, "Standard Procurement Policies and Practices," describes controls for LM\&OT procurements.

\subsection{Vendor Qualification and Qualified Bidder Assessment}

The LM\&OT suppliers and subcontractors are evaluated and qualified through the process described in NIF Procedure 7.1, "Procedure for Supplier Qualification."

\subsection{Vendor Surveys}

Verification of supplier compliance with quality requirements of Q-Levels 1 and 2 optical components during the production phase will be performed by qualified personnel in accordance with NIF Procedure 7.3, "Vendor Surveillance." This activity will include source inspections and reviews of suppliers' production and inspection records and other documentation verifying the achievement of quality at the source. Verification of compliance with quality requirements for Q-Level 3 components during production will be obtained by vendor certification or other means. 


\subsection{Inspection and Acceptance Testing}

Criterion 8 of the NIF QAPP, "Inspection and Acceptance Testing," requires the implementation of work processes that:

- Use established acceptance and performance criteria to conduct inspection and acceptance testing.

- Calibrate and maintain equipment used for inspection and tests.

Implementation procedures for PACE activities specific to this organization will not occur until the pilot production phase of work (in parallel with Title II engineering). Unique OPC-funded activities are described in Section 8.0.1.

The status of optical components is identified throughout the manufacturing process in accordance with NIF Procedure 5.4, "Component Identification and Tagging." Equipment used in inspection and testing activities is determined by the management planning activities described in Section 1.2. Instruments are controlled as described in Section 5.2.

\subsubsection{Material review and disposition during optics facilitization and pilot production}

During Title I and II engineering design, the LM\&OT organization will be greatly involved in optics facilitization and pilot production activities. This OPC-funded work is described in the Title I Design Plan (L-20357-1, NIF-95-650). These activities occur prior to optical component production, which is scheduled to start in FY98 with longlead procurements starting in FY97. This work is contained in Sections 1.11.6.1 and 1.11.6.2 of the NIF Project WBS (see Table 1-3, NIF Optical Component WBS).

Materials or components received under this scope of this work are inspected at LLNL or, prior to shipment, at the vendor site. Inspection includes review of the documentation accompanying the material or components by the technical authority identified in Section 1.2. This inspection will separate the materials or components into two groups:

1. Conforming to specifications-These parts are fully conforming to all specifications included in the purchase contract. As such, the materials or components are accepted for unrestricted use.

2. Nonconforming to specifications-These parts are found deficient in some respect. As such, they are subject to Materials Review Board (MRB) review and disposition prior to restricted use or outright rejection.

The composition of the MRB varies according to the material or components to be disposition. In general, the MRB will consist of the following:

- The NIF Optics Production Manager (Chairperson).

- The Lead Engineer/Scientist for Optical Component Development of the parts in question. 
- A representative of the NIF Special Equipment organization (composed of WBS 1.3, 1.4, 1.5, 1.7, 1.8 activities).

- The Optics QA/Metrology Engineer (Secretary).

- Others (i.e., Operations personnel) deemed necessary by the Chairperson, including Project Office representation

The MRB meets as frequently as necessary for prompt disposition of materials and components subject to their jurisdiction.

\subsection{Inspection}

Four inspections are conducted by LM\&OT personnel and subcontractors for NIF optical components: in-process inspections; final fabrication inspection; source inspection; and receiving inspection. In-process inspections and final fabrication inspections are performed by qualified subcontractor personnel in accordance with procedures generated by the manufacturer and approved by the LM\&OT organization's technical authority as described in Section 1.2. NIF personnel witness critical inspections of selected Q-Level 1 and 2 components. NIF QA personnel periodically witness inspections as a part of the surveillance and assessment processes addressed in Sections 7.3 and 10.0. Source inspection and receiving inspections will be performed according to the NIF Optics Metrology Plan, the NIF Optics Production Plan, and the NIF Optics Processing and Handling Plan.

\subsection{Acceptance tests}

Final acceptance of optical components is verified by the LM\&OT organization's technical authority described in Section 1.2, to ensure completeness and accuracy of data, compliance with acceptance criteria, and test configuration. NIF QA personnel may witness tests as a part of the surveillance and assessment processes addressed in Sections 7.3 and 10.0.

\subsection{Certification of Vendors}

Certification of optical component suppliers will be based all or in part on the outcome of trials conducted during the development and pilot production phases. Vendor certification involves approval of the following:

- Vendor facilities and equipment.

- Personnel qualification and training.

- Procedures describing work processes.

LM\&OT optics suppliers and subcontractors are evaluated and qualified through the process described in NIF Procedure 7.1, "Procedure for Supplier Qualification." 


\subsection{Management Assessment}

Criterion 9 of the NIF QAPP, "Management Assessment," requires that managers:

- Periodically assess the integrated management system at all management levels.

- Identify and correct problems that hinder the Project from achieving its objectives.

The LM\&OT organization participates in periodic self-assessments conducted by the NIF Project Manager and/or the Project Engineer as required by the self-assessment plans. The APL, the Optics Production Manager, and Lead Engineers/Scientists may independently determine the need to evaluate ongoing activities within the organization, regardless of other Project assessments. When so determined, internal assessments are conducted using NIF Procedure 9.2, "Management Self-Assessments," for guidance. 


\subsection{Independent Assessment}

Criterion 10 of the NIF QAPP, Independent Assessment," requires the implementation of processes that:

- Plan and conduct periodic independent assessments to measure effectiveness.

- Provide sufficient authority and freedom for the independent organization to conduct its assessments.

- Ensure that personnel conducting the independent assessment are technically knowledgeable in the area assessed.

The NIF Project QA organization schedules, plans, and conducts periodic assessments, audits, and other reviews to evaluate the line organizations' achievement of requisite quality objectives. This system of QA oversight is designed to advise management of potential problems and makes use of technically knowledgeable advisors working with QA evaluators to focus on the effectiveness of the LM\&OT organization, its performance, and its results.

Independent assessments of the LM\&OT organization's activities are conducted in accordance with NIF Procedure 10.1, "Independent Assessments." 


\section{Appendix A. \\ Laser Materials and Optical Technology Implementing Documents}

\begin{tabular}{|c|c|}
\hline QA criteria & LM\&OT Implementing documents \\
\hline 1. Program & $\begin{array}{l}\text { - this document } \\
\text { - Title I Design Plan } \\
\text { - NIF Project WBS } \\
\text { - Optics Metrology Plan (in prep.) } \\
\text { - Optics Handling and Processing Plan (in prep.) } \\
\text { - Optics Production Plan (in prep.) } \\
\text { - NIF Acquisition Plan (in prep.) } \\
\text { - NIF Procedures 1.2, } 1.3,1.4 \\
\text { - NIF Procedure 1.6: Assignment of quality levels }\end{array}$ \\
\hline $\begin{array}{l}\text { 2. Personnel qualification and } \\
\text { training }\end{array}$ & $\begin{array}{l}\text { - NIF Procedure 2.1: Personnel qualification and } \\
\text { training } \\
\text { - NIF Procedure 2.2: Personnel training }\end{array}$ \\
\hline 3. Quality improvement & $\begin{array}{l}\text { - NIF Procedure 3.2: Nonconformance reporting } \\
\text { - Sec. 8.0.1 (this document): Material review and } \\
\text { disposition during facilitization and pilot } \\
\text { production }\end{array}$ \\
\hline 4. Documents and records control & $\begin{array}{l}\text { - NIF Procedure 4.1: Document and records control } \\
\text { - NIF Procedure 4.2: Control of project } \\
\text { correspondence } \\
\text { - NIF Procedure 6.4: Configuration data } \\
\text { management (in prep) }\end{array}$ \\
\hline 5. Work processes & $\begin{array}{l}\text { - NIF Procedure 5.1: Title I design review } \\
\text { - NIF Procedures TBD: Metrology instrument } \\
\text { calibration. } \\
\text { - NIF Procedure 5.4: Component Id and tagging } \\
\text { - Optics Processing and Handling Plan } \\
\text { - NIF Procedure 5.3: Test and evaluation of } \\
\text { prototype optical components } \\
\end{array}$ \\
\hline 6. Design & $\begin{array}{l}\text { - NIF Procedure 6.1: SDR preparation } \\
\text { - NIF Procedure 6.2: ICD preparation } \\
\text { - NIF Configuration Management plan } \\
\text { - NIF Procedure 6.3: Engineering drawing } \\
\text { standards and control } \\
\text { - NIF Procedure 6.4: Configuration data } \\
\text { management } \\
\text { - NIF Procedure 5.1: Title I design review } \\
\text { - NIF Procedure 3.2: Nonconformance reporting. }\end{array}$ \\
\hline
\end{tabular}




\begin{tabular}{|l|l|}
\hline \multicolumn{1}{|c|}{ QA criteria } & \multicolumn{1}{|c|}{ LM\&OT Implementing documents } \\
\hline 7. Procurement & - NIF Acquisition Plan \\
& - NIF Optics Production Plan \\
& - NIF Procedure 7.1: Supplier qualification \\
& - NIF Procedure 7.2: Standard procurement practices \\
& - NIF Procedure 7.3: Vendor surveillance \\
\hline 8. Inspection and acceptance testing & - NIF Procedure 5.4: Component id and tagging \\
& $\begin{array}{l}\text { - Sec. 8.0.1 (this document): Material review and } \\
\text { disposition during facilitization and pilot production }\end{array}$ \\
\hline - NIF Procedure 7.1: Supplier qualification
\end{tabular}




\section{Appendix B. \\ Laser Material and Optical Technology Organization Chart}

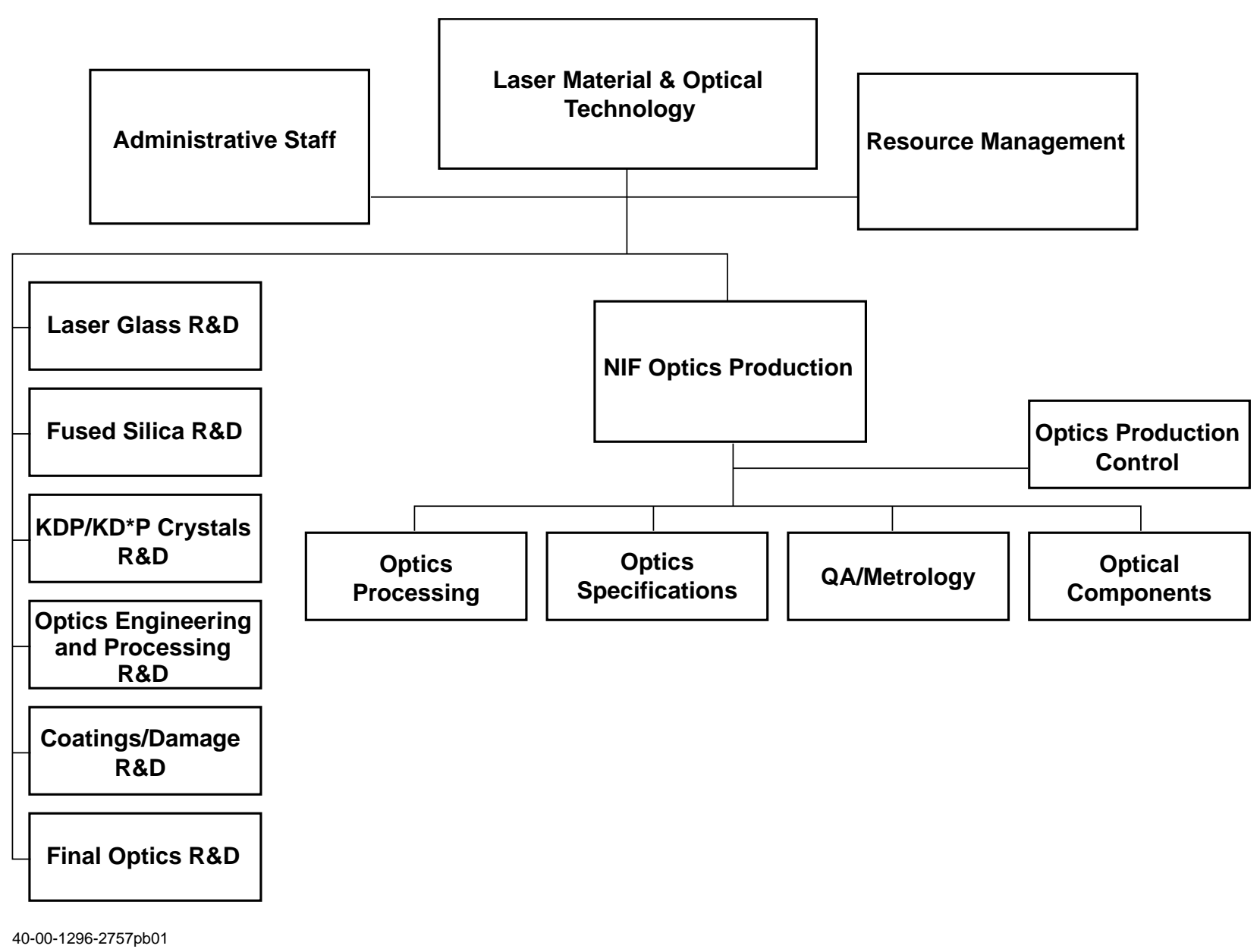


